\title{
Construction of the Practical Teaching System of Business English Major in the Local Application Universities - A Case Study of Business English Major at Xiangnan University
}

\author{
Xuan Chen, Zhenhua Chen, and Dewei Zhang
}

\begin{abstract}
Practice teaching plays a very important part in the business English professional personnel training system, and it can not only integrate and connect relevant knowledge, and promote the coordinated development of a variety of skills, but also cultivate the compound and applied talents who can meet the requirements of the development of social economy. In this paper, the author takes the business English major of Xiangnan University as an example, analyzes the current situation of the practice teaching of business English major, and attempts to construct a practical teaching system of business English major in the local application universities.
\end{abstract}

Index Terms-Business English major, construction, local application universities, practical teaching system.

\section{INTRODUCTION}

As the development of economic globalization and the increasing exchange of information, our society is badly in need of compounded business English talent who is not only proficient in English but also familiar with international business knowledge and skills. Compounded business English talent is also well welcomed in our society and foreign trade enterprises [1]. National medium and long-term educational reform and development plan (2020) points out explicitly that the history mission of higher education is to cultivate a large number of international talents who have wider international field of vision, proficient in international rules and involved in international business and competition. The ministry of education has approved 293 undergraduate universities to set up business English undergraduate major by the end of 2016. Xiangnan University has involved in business English teaching since 2003, and successfully set up business English major in 2015. We realize that we should not only pay attention to the training of students' English communication skill, but also their basic business knowledge and skills. And practice teaching plays important role in cultivating students' compound skills, practical and innovation ability. Therefore, it is very important to cultivate students' business skills by constructing business English course system, especially building a scientific and feasible

Manuscript received September 11, 2017; revised October 27, 2017.

The authors are with the Xiangnan University, China (e-mail: 418168938@qq.com,974695089@qq.com,45380338@qq.com). business English practical teaching system [2].

\section{The Problems In Business ENGLish PRACTICE TEACHING}

As a new major, there exist some problems in business English teaching, especially in constructing practical teaching system. We have investigated the talent training programs, teaching quality and employment of students in some local application universities, and found out most business English professional teaching focus on theoretical teaching while ignoring practical teaching, thus leading to the failure in cultivating qualified business English talents and satisfying the needs of international business activities.

Unclear Practical Teaching Goal. Business English is a strongly applicable and comprehensive discipline combined with theoretic and practical courses. It covers a wide range, but as a new major, influenced by traditional English and English education major, it has a vague position. What kind of ability students should have is not clear, so most local application universities have no clear idea how to construct a scientific practical teaching system.

Single Curriculum Content. Usually, teachers train students single business skill, and the content of practical teaching is arranged by teachers based on the teaching courses. So there isn't a complete business English practical teaching system. For example, Business English Audio-visual Teaching is only to train student's listening and speaking ability in business environment. Import and Export Business and Documents is only to cultivate student's ability to do international business and make documents. Business English Correspondence is mainly to train student to write foreign trade correspondence. Other practical courses are similar in content and format. These modes of practical teaching actually improve student's single skill, but can't satisfy the need of modern workplace, since what enterprises need is the high-quality and comprehensive skilled personnel.

Inexplicit Evaluation Standard of Practical Teaching Effect. Teachers usually evaluate students' practical ability through arranging course assignments and practice report. There isn't quantization standard for evaluating students' ability in practical training, team cooperation, and solving actual business problems. Therefore, teachers couldn't fully understand the effect of the business English teaching, and at the same time students haven't clear idea about their language and business abilities. As a result, students' 
enthusiasm and creativity is strangled.

Few and Uncompleted Practice Teaching Bases. Because of the insufficient investment and a small number of serial laboratories and training rooms, most local application universities haven't qualified practice teaching bases. Currently, most of the practice teaching bases adopt "Simulated company online + computer + software" to simulate the real international business transaction. However, simulated training is simple and lacks complicated, variable, flexible factors and information of the real business transaction, thus leading to failure in cultivating the professional skills of business English talents

In conclusion, it's very urgent to construct an effective practical teaching system for business English majors. In recent years, as a local application university, our business English teaching team in Xiangnan University have explored and constructed a feasible practical teaching system for business English majors, which has played a positive role in developing students' personality and training versatile business talents.

\section{The Construction of Practical Teaching Syestem FOR BUSINESS ENGLISH MAJORS}

Practical teaching system for business English majors should include five modules: language skill, business skill, intercultural communication competence, humanity quality and comprehensive ability (see Fig. 1.) We shall organize students to take part in all kinds of practical activities, such as cognitive practice, simulation training, business practice, graduation design, social practice, so as to enable students to master English knowledge and international business knowledge and skills, and thus cultivate students' strong practical ability and innovation spirit [3].

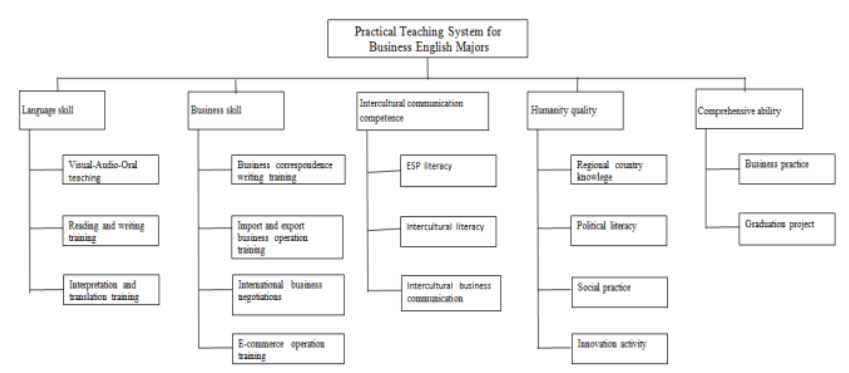

Fig. 1. Practical teaching system for business English majors.

\section{A. Language Skill Module}

Jones and Alexander called business English"English for business"or"English used in business contexts" [4]. Wang Xingsun believed"Business English is actually English is used in business environment, and it is an ESP for specialty talent in business lines" [5]. As ESP, business English is a tool in business activities, and it emphasizes language skills of listening, speaking, reading, writing and translation. We shall realize the different characteristics of language learning and business disciplines, and pay attention to English language knowledge study and language skills training in college freshmen and sophomores. Teacher shall choose the content of language training carefully, design feasible training methods, and strengthen training of students' listening, speaking, reading, writing and translation skills, so as to lay a solid language foundation for students' future business study.

\section{B. Business Skill Module}

Business skill is the foundation for students to engage in international business activities, which is also a relatively weak part of business English majors. According to the actual needs of the students, we shall set up several business courses from the sophomore year, such as international trade and practice, international marketing, business negotiations, $e$-commerce and international finance. Only by simulating some real "business scenes", and training student's business skills, such as how to write business letters, how to negotiate business, how to sign and perform business contract, how to make international payment, and how to deal with the disputes and claims, can we help students to understand and master all the business procedures and methods, and thus benefit students engaging in business matters.

\section{Intercultural Communication Competence Module}

Language is a tool of communication as well as a carrier of culture. Language competences include linguistic knowledge and pragmatic knowledge, as well as cultural knowledge of target language. Therefore, in business environment, the ability to use English to communicate and collaborate effectively is in fact an intercultural communicative competence. In this module, we should cultivate students' intercultural communication competence by some training courses, such as cross-cultural business communication theory, international business communication, international business etiquette, international business negotiation, international business culture and public speech.

\section{Humanity Quality Module}

As a basic content of quality education, humanistic quality education could enrich students' the spiritual world, help students to rationally cognize the world, the nation and the society, and cultivate their national spirit and enhance their spiritual strength. As students, in addition to their professional skills, they also need to have spirit of self-improvement, noble personality and broad mind. And these skills can be obtained in political, military, social, and innovative training projects.

\section{E. Comprehensive Ability Module}

It mainly includes the student's business practice and graduation project. After each single skill training, students should be arranged in simulated or real "business scene" to combine and integrate each single skill through comprehensive skills training. On base of school-enterprise cooperation program, we shall provide students with the condition and places for visit, cognition, probation and practice, etc., which plays a very important role in improving students' business practical ability.

\section{CONCRETE IMPLEMENTATION OF PRACTICAL TEACHING IN BUSINESS ENGLISH MAJOR}

As a local application university, supported by our university and foreign language college, business English 
teaching team of Xiangnan University has made great progress in business English practical teaching. Based on our experience and lessons in the reform of business English practical teaching, our concrete implementation of practical teaching is as follows.

\section{A. Make Clear Practical Tasks, and Simulate Business Activities}

In terms of the practical courses, we attach great importance to the cohesion between English courses and business courses, consolidation and expansion of English knowledge and language skills, and cultivation of business skills and professional abilities. According to talents training program of business English, we shall make clear teaching objectives and practice tasks, select proper training content, and use correct teaching methods and practical training form. Besides, we have carefully designed scenarios of business activities, and used multimedia network and other means to provide students with pictures, text, images or computer animation in relevant business training project, so as to arouse students' attention and interest. Through simulating kinds of scenes, such as international social activities, international trade negotiations and international business meetings, let students establish their own learning tasks and learn how to use business knowledge to analyze and solve business problems, thus training their business communication skills in listening, speaking, reading and writing, and improving business communication skills at the same time [6].

\section{B. Emphasize Construction of Training Room and Constantly Improve Practical Teaching Conditions.}

Practical teaching conditions, especially practical training bases, are the basic guarantee for effective implementation of practical teaching. Business English major, restricted by occupation, nature of work, time and other factors, some important special skills, such as business negotiation, documentation making, foreign trade correspondence writing, customs clearance, can't be trained and performed comprehensively and systematically. Therefore, it is very important to establish a complete training room inside school, especially simulation training room. In recent years, in order to meet the actual needs of business English major, we have constructed 14 digital language laboratories, 1 import and export simulation training room, 1 international business negotiation room and 1 simultaneous interpretation training room. Besides, we focus on the construction of practical training base and set up several international trade companies. Students are directly involved in some business trade, and students' professional training scores depend on their real business performances. Meanwhile we let students share marketing profit. In this way, it not only fully mobilizes and inspires students' positivity in practical training, but also helps students to understand the real commodity, market, customer and procedures in international trade, and thus improve their international business abilities.

C. Stabilize and Expand Outside-school Practice Bases, and Improve the Practice Quality.

After a few years of exploration, we have established in-school training bases as the core, and stably, gradually expand outside-school practice bases with schools, enterprises and governments. Up to now, we have set up 4 outside-school practice bases in Guangzhou, Shenzhen, Dongguan and Huizhou. On one hand, we invite enterprise experts as our tutors for practical teaching; on the other hand, outside-school practice bases accept our business English students as trainees, and cultivate students' language and business practical ability in real business environment. In addition, based on win-win cooperation and mutual benefit, we also help the enterprises to train their staff's English. By continuously expanding outside-school practice bases, we have created favorable conditions for the qualified practice.

\section{Carry out Diversified Assessments and Enhance the Validity of Practical Teaching Evaluation}

In traditional English teaching, the standards to assess students is mainly the final exam results, which is not conducive to the development of students' independent thinking, speculative and problem-solving ability. Therefore, in the ways of the evaluation for practice teaching, we shall integrate various evaluation contents, themes and methods, and carry out diversified assessment and evaluation.

Further improve content of evaluation. We shall change single evaluation into a full range of evaluation, including final examination and practical operation, to test students' basic knowledge, ability, and the attitude of practical operation, which also reflects the requirements of evaluation that knowledge should be combined with skills, processes with methods, learning with cooperation, and attitudes with values, etc.

Diversify examination methods and improve forms of assessment and evaluation. We have constantly improved the traditional examination method, namely ordinary achievement (30\%), and term examination (70\%), and emphasize the assessment of students' ability, knowledge and quality. By combining process assessment with final assessment, it can not only assess students' understanding and application ability of various kinds of knowledge and skills, but also take into account the attitude and seriousness of students in participating practical training.

Let students involve in the assessment of their own learning process. Usually the practical teaching process is a long time, and it is difficult for instructors to understand all students' performance in a short period of time. So we let students involve in assessing each other. At the same time, the teachers' assessment must occupy the predominance, and then students judge themselves each other. In this way, it will not only improve the quality of assessment, but also the quality of business practical teaching.

Let enterprise involve in students' assessment. In order to assess students' learning effect in all aspects and improve students' learning ability and comprehensive quality, we shall establish a college-enterprise joint evaluation mechanism on the basis of self assessment and teachers' assessment, inviting enterprise' professional staff to assess the practical ability of students, and strengthening the effectiveness of assessment. Thus the assessment of practical teaching for business English will be more effective and comprehensive. 


\section{ACKNOWLEDGMENT}

This study is supported by National College Students Innovation Experiment Project in 2017 (A survey of the development of cross-border e-commerce and the demand for business English talents in Xiangnan area under the "new normal" economy, item number 201710545004).

\section{REFERENCES}

[1] X. J. Sun, "Construction of practical teaching system for business English majors from the perspective of demand theory," Journal of Hubei University of Economics(Humanities and Social Sciences), vol. 11, pp. 184-186, Nov. 2008.

[2] X. G. Zhao and H. J. Zhao, "Construction and implementation of practical teaching system for business English majors," Financial Teaching and Research, vol. 2, pp. 66-67. Feb. 2008.

[3] Z. M. Chen and L. F. Wang, Teaching Requirements for Business English Majors in the Institution of Higher Education, Beijing: Higher Education Press, 2009, pp. 1-9.
[4] L. Jones and R. Alexander, International Business English Student's Book, Cambridge: Cambridge University Press, 1994, p. 36.

[5] X. S. Wang, An Explore on the Development of International Business English, Shanghai: Publishing House of Shanghai Jiao Tong University, 1997, p. 31.

[6] Y. L. Li, "On new exploration of practice teaching of business English under constructivism theory," Journal of Hunan University of Commerce, vol. 5, pp. 126-128, May 2009.

Chen Xuan was born in July, 1981, in Chenzhou, Hunan province. The author is lecturer of Xiangnan University. Graduated from Dongbe University of Finance and Economics, majoring in international business English. The author got the master's degree specializing in business English teaching and pragmatics.

Chen Zhenhua was born in July, 1997, in Huaiha, Hunan province. He is a student of foreign language college, Xiangnan University, majoring in business English.

Zhang Dewei was born in May, 1997, in Guangzhou, Guangdong province. $\mathrm{He}$ is a student of foreign language college, Xiangnan University, majoring in business English. 